\title{
An Examination Of Underreporting Of Time And Premature Signoffs By Internal Auditors
}

Qianhua (Q) Ling, Marquette University, USA Michael D. Akers, Marquette University, USA

\begin{abstract}
The passage of the Sarbanes-Oxley Act of 2002 (SOX) heightened the importance of internal controls and accordingly, a key control - the internal audit function. Consequently, management and external auditors have both increased their reliance on internal auditors' work. While there has been considerable research regarding the impact of the underreporting of time and premature sign-offs on the external audit, there has only been one study that has examined the impact of these two items on the internal auditors' work. Such research is dated (1994) and prior to the passage of SOX. We surveyed members of the Institute of Internal Auditors (IIA) in the Midwest to examine their behavior and perceptions regarding these two items. The respondents in our study believe the underreporting of time is unethical and is supported by their reporting of all time worked, even if such time exceeded the budget. Our findings also show that the respondents feel premature sign-offs are unethical and result primarily from lack of professional skepticism and inadequate training. Increasing training in audit areas and improving communications within the audit team are possible solutions to reduce premature sign-offs. Premature sign-offs are more likely to occur in operational audits and to a lesser degree in financial audits and compliance audits.
\end{abstract}

Keywords: internal auditing; underreporting time; premature signoffs

\section{INTRODUCTION}

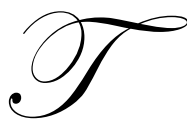

he underreporting of time and premature sign-offs can negatively impact the quality of audit work by internal auditors, which can then impact an entity's external audit. While research on these two items has been extensive for external auditors, there has been very little research on underreporting of time and premature sign-offs by internal auditors. We found only one study (Azad 1994) that examined these two issues and internal auditors. Such research is dated and therefore needs to be updated. How these two issues can impact an internal audit function is important for an entity's Board of Directors, Management, and Director of Internal Audit to understand.

AU 322 (SAS 65) states that an auditor considers many factors in determining the nature, timing and extent of audit procedures performed in an audit of an entity's financial statements. One of those factors is the existence of an internal audit function. An important responsibility of the internal audit function is to monitor an entity's internal controls, and the independent auditor has a responsibility to gain an understanding of internal controls to plan and conduct the audit. AU 322.05 indicates that the external auditor should make inquiries of management and internal audit personnel about the following items related to the internal audit function - organizational status, application of professional standards, such as those developed by the Institute of Internal Auditors, audit plan (including the nature, timing and extent of audit work) and access to records, and whether there have been any scope limitations of their activities. Furthermore, AU 322.06 indicates that the external auditor might inquire about the internal audit function's charter, mission statement or similar directive from management of those charged with governance. Such inquiry will provide information about the goals and objectives of the internal audit function. In addition to 
impacting the quality of the internal auditor's work and potentially the external audit, the underreporting of time and premature write-offs both have training and supervision implications that the Director of Internal Audit should consider.

Two sections (Section 2330-Documenting Information and Practice Advisory 2330-1 and Section 2340Engagement Supervision and Practice Advisory 2340-1) of the Institute of Internal Auditors (IIA) International Standards for the Professional Practice of Internal Auditing are relevant to underreporting of time and premature sign-offs. Practice Advisory 2330-1 states that engagement working papers generally aid in the planning, performance and review of the engagements, support the accuracy and completeness of the work performed, and document all aspects of the engagement process, from planning to communication results. Such guidance suggests that ALL work (hours and procedures) should be documented. Practice Advisory 2340-1 states that supervision includes "ensuring the approved engagement program is completed unless changes are justified and authorized and determining engagement working papers." Engagement supervision also holds the chief audit executive responsible for developing policies and procedures designed to that all engagement working papers are reviewed to ensure they support engagement communications and necessary audit procedures are performed. Such guidance suggests that both the underreporting of time and premature write-offs result in inaccurate reporting and communication of audit results.

We conducted a study that examined the underreporting of time and premature write-offs by internal auditors. The first section of the paper summarizes relevant research that examined the underreporting of time and premature sign-offs by internal auditors. Section two explains the design of our study and the demographic data of the participants. Section three reports our findings and the final section provides concluding observations.

\section{PRIOR RELEVANT RESEARCH}

Considerable research has been done on the underreporting of time (Kelley and Margheim 1987, Otley and Pierce 1996, Akers and Eaton 1999, 2003) and premature sign-offs (Reckers et al. 1997 Alderman and Deitrick 1982) for external audit. A recent study modeling internal auditor independence includes time pressure as a factor based on the Azad (1994) study (Ahmad and Taylor 2009). Azad (1994) is the only research that has examined the underreporting of time and premature sign-offs among internal auditors. He mailed a survey to members of the Institute of Internal Auditors (IIA), in particular, from the Atlanta, Dallas/Fort Worth, Houston, and Los Angeles chapters. The response rate was about $41 \%$ (262 / 638 questionnaires). He found that time budgets produced significantly negative consequences. Internal auditors tried hard to stay under time budgets. Many internal auditors (68.7\%) worked on their own time to meet the time budget. More than $70 \%$ agreed to use their own judgment to override some audit procedures. In addition, premature sign-offs widely existed (38\%). This occurred mostly in compliance auditing, followed by operational auditing and financial auditing. Internal control, inventory, and fixed assets were most susceptible to premature sign-offs. Pressure from time budgets was identified as one top reason that internal auditors engaged in premature sign-offs. Correspondingly, deemphasizing time budgets was one possible way to solve the premature sign-off problem. Overall, underreporting time and premature sign-offs appeared a prevalent and serious problem more than a decade ago.

We expect that this situation may change over time, especially after the passage of the Sarbanes-Oxley Act of 2002 (SOX). SOX has changed the landscape of business operation from at least two perspectives. First, Section 404 of SOX requires management and the external auditor to report on internal control on financial reporting. It creates greater reliance on internal auditors and their work (Carcello et al. 2005a, Hermanson et al. 2008). This is because the key role of internal auditors is to add value to an entity's risk management, control, and governance processes (IIA 2010). Some evidence shows that the reliance on the internal audit function significantly increases resources such as audit budgets, staffing levels, and their contacts with the audit committee (Carcello et al. 2005b).

Second, SOX promotes ethical behaviors to restore public confidence in the stock market. Section 406 of SOX requires all public companies to have a written code of conduct. Following that, some stock exchanges require that everyone in the company should be covered by the code (Verschoor 2004). The 2004 revision of the U.S. Sentencing Guidelines (USSG) further requires organizations of any kind to promote a cultural of ethical conduct (Verschoor 2007). Research shows that the code of ethics emphasizes more on compliance in the post-SOX era than 
in the pre-SOX era (Canary and Jennings 2008). If internal auditors consider underreporting time and premature sign-offs unethical, we expect that these issues in today's environment will not be as serious as in the past.

\section{STUDY}

\section{Survey}

We used a survey to investigate the issue of unrecorded reportable time and premature sign-offs among internal auditors. To enhance comparability, we included many of the questions that Azad (1994) used to examine underreporting of time and premature write-offs of audit procedures. We also included questions from prior research (Akers and Eaton 2003) that examined the underreporting of time by external auditors. The questionnaire was then reviewed by nine internal auditors. Based on their feedback we made minor revisions to the questionnaire. Using SurveyMonkey.com, an introductory paragraph, which explained the study, and the revised questionnaire were posted online. SurveyMonkey allowed the respondents to complete the survey online and also guaranteed anonymity. Email invitations were sent to three Wisconsin chapters (Fox Valley, Madison, and Milwaukee) and three Northern Illinois chapters (Chicago, Chicago-West, and Northwest Metro Chicago) of the Institute of Internal Auditors (IIA). The first invitation to the survey was sent out for 15 days. The second invitation to the survey was sent out for ten days. We received 123 responses in total out of the population of 3,571 chapter members. Among the 123 responses, 96 responses ( 78 percent) were received on the first two days of the survey. The response rate is low, approximately $3.4 \%$. Based on the requests for the survey results, we infer that most of the responses came from the three Wisconsin chapters (835 members). If this is correct, the response rate is approximately $14.7 \%$.

\section{Demographic Data}

Table 1 presents the demographic data that we collected about the respondent's organization (public, private, not-for-profit, and size of internal audit department) and the respondent (gender, professional certifications, experience-internal and public, position). Our respondents are from different types of organizations as approximately $43.1 \%$ are with publicly traded companies, followed by $35.0 \%$ from privately held companies, $12.2 \%$ from non-for-profit organizations, and the remaining 9.8\% from government agencies. While the size of the internal audit department varies from 1-5 employees to more than 50 employees, most (92.6\%) of the respondents are with departments of 30 or fewer employees. Only $7.4 \%$ report a department size greater than 30 employees.

More than half (54.1\%) of our respondents are female which is higher than Azad's (1994-28.7\%) results. Considering the increase in female accounting majors during the past 15 years we aren't surprised that the percentage of female respondents is higher than the Azad study. It is, however, interesting that the majority of the respondents are female when considering the positions of the respondents. Approximately $43 \%$ are either the Director of internal audit (19.7\%) or an Audit Manager (23\%) while slightly more than half (52\%) of the respondents are an Audit Senior/Supervisor (27\%) or Staff Auditor (25.4\%). The majority (70.7\%) of our respondents have some type of professional certification with the CPA $(51.2 \%)$ most frequently cited followed by the CIA (23.6\%). And thirty-five respondents (28.5\%) have two or more professional certifications. More than $60 \%$ of respondents have more than five years of internal audit experience and only $3.3 \%$ of them have less than one year of experience. While a lot of the respondents have public accounting experience it is interesting to note that $45.5 \%$ of them have no experience in public accounting at all.

\section{RESULTS}

\section{Underreporting of Time: Ethical Implications}

The second section of our survey is on time budgets and inaccurate reporting of time. These questions focus on the control mechanism, reporting time, the use of time budgets on performance evaluation, the current preparation of time budget, internal auditors' attitude to time reporting, and actions they may take under time pressure. The results are reported in Tables 2 and 3. Table 2 provides our findings regarding organizational issues related to time reporting - the existence of organizational policy on time reporting, supervisor's request to underreport time, respondent's unrecorded reportable time during the prior year and the organizational level that 
reviews time reports for performance evaluation. Table 3 shows the respondents' perceptions regarding the underreporting of time and impact of time budgets on internal auditors' behavior.

\section{Underreporting of Time: Organizational Issues Related to Time Reporting}

As reported in Table 2, $41 \%$ of respondents report that their organization has a policy regarding accurate time reporting. However, among those with a policy, only $40 \%$ have some sanctions for violating the policy. Sanctions identified by the respondents include: verbal warning, warning/discussion with management, disciplinary action, and termination. The following responses are particularly interesting: "Falsification of records (including time records) is considered 'misconduct in public office' (a felony);" and "Our department does not track audit hours or time budgets. Generally, we conduct tailored/scoped audits that are assigned deadlines for reporting. So we manage by audit deadline, as opposed to hourly reporting." Although the development of a policy regarding accurate time reporting and the use of sanctions are not widely adopted by the respondents' organizations, $73.6 \%$ of the respondents report that the reporting of time is reviewed for performance evaluation. Twenty-eight percent report that the reporting of time is reviewed by two or more levels.

Supervisors may put pressure on internal auditors to underreport time as in external audit (Akers and Eaton 2003). Our findings suggest that this isn't an issue for the respondents. None of the respondents note that supervisors, male or female, requested them, either explicitly or implicitly, to frequently underreport time. Only $2 \%$ (requested by female supervisor) and 3\% (requested by male supervisor) of the respondents are explicitly requested to occasionally underreport time, and 5\% (requested by female supervisor) and 7\% (requested by male supervisor) are implicitly requested to underreport time. Despite the lack of pressure from supervisors, $23.3 \%$ (21 of the 90 that responded to this question) of the respondents state that they underreported time during the past year. While the range of underreported time is $1 \%$ to $30 \%$, the average underreported time is $6.8 \%$.

\section{Perceptions Regarding the Underreporting of Time and Impact of Budgets on Auditor Behavior}

In Table 3, responses to our questions are grouped by opinion, from strongly disagree, disagree, indifferent, agree, to strongly agree. We report the results in percentages based on the actual number of responses to the question. We also assign values one to five with one representing "strongly disagree" and five representing "strongly agree." Using a mean value above 3.50 and below 2.50 as an indication of agreement or disagreement, there are only three questions in Table 3 (questions 13,16 and 23) that fall in this range and one other question that is close (question 17 , mean $=3.45$ ). While these findings suggest that the respondents are indifferent to the issues, an examination of the responses for each question shows a lack of consensus by the respondents for most of the items. For many of the questions, the percentage of respondents that agree approximates the percentage of respondents that disagree.

Accordingly, we draw the following four observations. First, while approximately $7 \%$ disagree and $9 \%$ are indifferent, there is overall support that underreporting of time is unethical (mean $=4.08$ ). This provides some evidence that in the post-SOX era awareness of ethical behavior is high. Second, there is moderate support (mean $=3.81$ ) that the time budget is a necessary tool for the evaluation of an internal audit department. This finding suggests that time budgets aren't a major component in evaluating the performance of an internal audit department. Third, while there is only slightly moderate support (mean of 3.45), the majority of the respondents (approximately $65 \%$ ) indicate that attainment of the time budget is a factor in the auditor's performance evaluation. Fourth, most (77.1\%) of the respondents indicate that during the past 12 months, if they worked more than the budgeted hours, they reported the additional hours worked. This finding is consistent with the result that most respondents consider underreporting of time unethical.

\section{Premature Sign-offs: Ethical Implications}

In this study, a premature signoff is defined as signing off the required audit step(s) without completing the work or not noting the omission of the work and these steps are not covered by other audit procedures. A premature signoff affects the quality of an internal audit and can also impact an external audit if the external auditor relies upon the work of the internal audit department. Our findings on premature signoffs are reported in Table 4. Most (87.5\% 
either agree or strongly agree and mean $=4.17$ ) of the respondents perceive that premature sign-offs are unethical while 3.3\% either disagree or strongly disagree. This finding is consistent with the finding that only three respondents $(2.5 \%)$ admit that they signed off audit steps without completing or noting the omission of some audit procedures in the past 12 months and that few respondents (18.5\%) are aware that premature signoffs occur in their department $($ mean $=2.37)$. Consistent with these findings, the majority of the respondents $(75.2 \%)$ either disagree or strongly disagree (mean $=2.31$ ) that the auditor's professional judgment is sufficient to override the performance of a specific audit step, while the majority $(81.8 \%$ ) either agree or strongly agree (mean $=3.93$ ) that an auditor should never omit a planned procedure without consulting a supervisor.

\section{Reasons for Premature Sign-offs}

Regarding the reasons why premature signoffs occur (question 32) our findings show moderate support for the following six reasons: (1) inclination to readily accept operating personnel explanation (mean $=3.70)$, (2) an audit step appearing unnecessary or immaterial $($ mean $=3.68)$, (3) inadequate supervision $($ mean $=3.52)$, (4) lack of communication with supervisors (mean $=3.46)$, (5) lack of specific technical knowledge (mean $=3.45)$, and $(6)$ time budget constraint (mean = 3.39). Azad (1994) found four primary reasons for premature signoffs: (1) an audit step appearing unnecessary or immaterial (mean $=3.69)$, (2) inadequate supervision (mean $=3.61)$, (3) inclination to readily accept operating personnel explanation (mean $=3.62)$, and $(4)$ time budget constraint $($ mean $=3.61)$. While the rank order of the reasons differs, our findings are similar to Azad's (1994) findings with two exceptions communication and technical knowledge. Having technical knowledge is critical to produce quality audit work. The prior literature finds that without specific technical standards, the external auditor is less likely to be supported by the audit committee in an audit dispute and management tends to obtain outcomes in its favor (Knapp 1987). Our result suggests that without the appropriate technical knowledge, internal auditors tend to prematurely sign off audit procedures, which adversely affects audit quality. Our study incorporated the communication question as a result of pretesting while the Azad (1994) study didn't use a communication question.

\section{Procedures to Reduce Premature Sign-offs}

Our findings identify four ways to reduce premature sign-offs: (1) improved communication within the audit team (mean $=3.96)$, (2) training of auditable area $($ mean $=3.82)$, (3) de-emphasis of the time budget (mean $=$ 3.69), and (4) tighter supervision of inexperienced auditors (mean =3.58). Azad's top four solutions included improved communication within the audit team $($ mean $=4.12)$, tighter supervision of staff with less than two years' experience $($ mean $=3.63)$, increased variety of work assignments $($ mean $=3.57)$, and $(4)$ de-emphasis of the time budget $($ mean $=3.54)$. The findings of the two studies are once again very similar. Both studies find communication between auditors, supervision of inexperienced auditors and de-emphasis of the time budget as ways to reduce premature signoffs. Our study found training, a variable not used by Azad (1994), to be more important than variety of work assignment. The four methods identified above by our respondents are all stronger than the review process (question 31 ) where $60.5 \%$ (mean $=3.44$ ) believe that the review procedures in their department are adequate to detect premature sign-offs.

\section{Types of Audits and Premature Sign-offs}

The majority of our respondents (57.4\% either agree or strongly agree) state that operational auditing is the type of audit most likely to have premature sign-offs ( mean $=3.48)$, followed by financial auditing $($ mean $=3.20)$, and finally compliance auditing (mean = 3.06). Azad's (1994) findings are similar to ours with respect to operational auditing and financial auditing but there is a difference with respect to compliance auditing. Our results show a lower likelihood of premature sign-offs for compliance auditing than did Azad (1994), which is consistent with what Hespenheide (2006) observes that internal auditors shift their effort to SOX compliance. While the Azad (1994) study asked respondents to indicate what phase of the audit where premature sign-offs were likely to occur by using the following categories (internal controls, cash, receivables, inventory counts, other inventory work, fixed assets, payroll, accounts payable, debt, owner's equity, and revenue recognition), we used an open-ended question. The majority of our responses are categorized succinctly as follows: planning, gathering evidence, testing, execution, and fieldwork review. Below are more detailed comments that provide additional insights into our findings: 
Fieldwork in Operational audits that do not have traditionally defined work programs.

Operational auditing since our current focus is SOX and Compliance auditing.

Our audit approach requires professional judgment, risk analysis, and scoping. All Scoping decisions are to be documented. The problem with this approach is that we haven't developed the competencies in our staff to determine what is critical and what is not. Given our tight time-budgets, something "has to give", but our staff have difficulty determining what's critical and what's not As a result, they work OT or sign-off despite "rounding some corners", so to speak (ie accepting inquiry w/o corroboration). This (is) a short-coming of our management and training. Experienced auditors should be adequately trained and empowered to "shift on the fly". New staff should be monitored more closely.

These comments are consistent with our finding that one way to reduce premature sign-offs is through better training. Operational audits, which focus on the efficient and effective use of resources, often use audit procedures that vary from procedures used in financial type audits or specific procedures used in a compliance audit. Considering the time and effort devoted to SOX by public companies and many private companies that implemented SOX although not required to do so, we aren't surprised that our findings showed less of a likelihood of premature sign-offs for financial and compliance audits as compared to operational audits.

\section{CONCLUSIONS}

Unlike public accounting firms, the majority of our respondents work for organizations that do NOT have policies regarding the underreporting of time. Although many of our findings regarding the underreporting of time suggest that the participants are indifferent, a close examination shows differing viewpoints. The participants believe underreporting of time is unethical and there is agreement that the respondents would report the time worked (question 25 a, Table 3), even if such time exceeded the budget. A small percentage of the respondents were asked by supervisors, female or male, explicitly or implicitly, to underreport time. Yet, internal auditors continue to underreport time (average time underreported was 6.8\%). Our findings also indicate that, while time budgets have become tighter in the past six years, the participants are indifferent that the time budget interferes with proper conduct of the audit. These findings are consistent with our expectation that underreporting time is a less severe problem post-SOX. Azad (1994) also found that time budgets were tightening; however, he found that the time budget did interfere with proper conduct of the audit. We found moderate support that the time budget is a necessary tool for evaluating the internal audit department as well as the performance of the internal auditor.

Regarding premature sign-offs, the respondents believe that such behavior is unethical, as evidenced by the very small percentage that reported doing so within the past twelve months. Other findings relate to training and the planning and conduct of the audit. The respondents don't believe that an auditor should omit a procedure without consulting a supervisor which pertains to communication within the audit team. Premature sign-offs result primarily from willingness to accept explanations by operating personnel, which suggests a lack of professional skepticism, inadequate supervision, perception of unnecessary audit step, lack of communication with supervisors, and lack of technical knowledge. With the exception of technical knowledge, our findings are consistent with Azad's findings. The respondents felt premature sign-offs could be addressed by better communication within the audit team, training of the audit area, de-emphasis of the time budget, and tighter supervision of younger staff (two years or less). Azad (1994) also identified better communication as the primary way of reducing premature sign-offs.

Our findings show that premature sign-offs are more likely to occur in operational audits and, to a lesser degree, financial audits and compliance audits while Azad found that premature sign-offs were more likely to occur in compliance and operational auditing, and to a much lesser degree, in financial audits. We believe our finding, in comparison to Azad's results, indicates that SOX testing by internal auditors has reduced the likelihood of premature sign-offs during compliance audits.

This study makes three primary contributions to the existing literature. First, it provides current evidence regarding two dysfunctional behaviors of internal auditors - underreporting of time and premature sign-offs. Second, this study adds to the internal audit literature as only one study has examined these issues and that study, 
which was conducted in 1994, is now dated. Third, this study extends the prior research by examining whether organizations have a policy on underreporting of time, requests by supervisors by gender, and using an open-ended question to determine why premature sign-offs might occur in compliance, financial and operational audits.

This study is subject to some limitations. First, although we have no reason to believe otherwise, internal auditors in Illinois and Wisconsin might not be representative of all internal auditors. Second, there are inherent limitations associated with the use of a survey instrument. For example, there is a potential for non-response bias or bias in the reporting of the data since underreporting time and premature sign-offs are sensitive subjects. Reckers et al. (1997) finds that using the direct method eliciting responses to sensitive issues, such as premature sign-offs, generates a lower level of reporting than using a randomized response approach. The incidence of underreporting time and premature sign-offs may be higher than what is reported in this study.

Based on our findings, future research should examine whether time budgets are used by internal audit departments and the reasons why. Regarding premature sign-offs, future research should examine what internal audit departments are doing to improve training for auditors and communication within the audit team and examine more closely how to reduce premature sign-offs in operational audits.

\section{AUTHOR INFORMATION}

Dr. Qianhua (Q.) Ling is an assistant professor of accounting at the College of Business Administration, Marquette University, Milwaukee, Wisconsin

Dr. Michael D. Akers, CPA, CIA, CMA, CFE, CBM is the Charles T. Horngren Professor of Accounting and Chair, Department of Accounting. He earned his doctoral degree at the University of Mississippi and his MBA at the University of Louisville. In addition to serving on the editorial advisory board of two journals, he has authored more than 60 articles in academic and professional journals. He currently serves on the Audit Committee and Board of Directors of two publicly traded companies.

\section{REFERENCES}

1. Ahmad, Z., and D. Taylor. 2009. Commitment to independence by internal auditors: The effects of role ambiguity and role conflict. Managerial Auditing Journal 24(9): 899-925.

2. Alderman, C.W., and Deitrick, J.W. 1982. Auditors' perceptions of time budget pressures and premature sign-offs: a replication and extension. Auditing: A Journal of Practice and Theory 1: 53-68.

3. Akers, M.D. and T.V. Eaton. 1999. Underreporting chargeable time: A continuing problem for public accounting firms. Journal of Applied Business Research: 15: 13-20.

4. Akers, M.D., and T.V. Eaton. 2003. Underreporting of chargeable time: The impact of gender and characteristics of underreporters. Journal of Managerial Issues XV(I): 82-96.

5. Azad, A.N. 1994. Time budget pressure and filtering of time practices in internal auditing: a survey. Managerial Auditing Journal 9: 17-25.

6. Canary, H.E., M.M. Jennings. 2008. Principles and influence in codes of ethics: A centering resonance analysis comparing pre- and post-Sarbanes-Oxley codes of ethics. Journal of Business Ethics 80 (2): 263278.

7. Carcello, J.V., D.R. Hermanson, and K. Raghunandan. 2005a. Factors Associated with U.S. Public Companies' Investment in Internal Auditing. Accounting Horizons 19(2): 69-84.

$8 . \quad 2005 \mathrm{~b}$. Changes in internal auditing during the time of the major U.S. accounting scandals. International Journal of Auditing (July): 117-127.

9. Gold, A., J.E. Hunton, and M.I. Gomaa. 2009. The Impact of client and auditor gender on auditors' judgments. Accounting Horizons 23 (1): 1-18.

10. Hermanson, D.R., D.M. Ivancevich, and S.H. Ivancevich. 2008. Building an effective internal audit function: Learning from SOX section 404 reports. Review of Business 28 (2): 13-27.

11. Hespenheide, E. 2006. Optimizing the role of internal audit in the Sarbanes-Oxley ear. Corporate Finance Review 10 (4): 27-37. 
12. Institute of Internal Auditors (IIA). 2010. International Standards for the Professional Practice of Internal Auditing. http://www.theiia.org/guidance/standards-and-guidance/ippf/standards/full-standards/

13. Knapp, M.C. 1987. An empirical study of audit committee support for auditors involved in technical disputes with client management. The Accounting Review LXII(3): 578-588.

14. Kelley, T. and L. Margheim. 1987. The effect of audit billing arrangement on underreporting of time and audit quality reduction acts. Advances in Accounting 5: 221-233.

15. Otley, D. T. and B.J. Pierce. 1996. The operation of control systems in large audit firms. Auditing: A Journal of Practice and Theory 15: 65-84.

16. Reckers, P.M.J., S.W. Wheeler, B.Wong-On-Wing. 1997. A comparative examination of auditor premature sign-offs using the direct and the randomized response methods. Auditing: A Journal of Practice and Theory 16 (1): 69-78.

17. Verschoor. C.C. 2004. Will Sarbanes-Oxley improve ethics? Strategic Finance 85 (9): 15-16.

18. 2007. How good is your ethics and compliance program? Strategic Finance 88 (10): 19-20. 
Table 1: Demographic Information

\begin{tabular}{|c|c|c|}
\hline & & Response Percent \\
\hline \multirow[t]{5}{*}{1} & Business type & \\
\hline & Publicly held & $43.1 \%$ \\
\hline & Privately held & $35.0 \%$ \\
\hline & Non-for-profit & $12.2 \%$ \\
\hline & Government & $9.8 \%$ \\
\hline \multirow[t]{3}{*}{2} & Gender: & \\
\hline & Female & $54.1 \%$ \\
\hline & Male & $45.9 \%$ \\
\hline \multirow[t]{7}{*}{3} & Professional certification status (choose all applicable) & \\
\hline & CIA & $23.6 \%$ \\
\hline & $\mathrm{CPA}$ & $51.2 \%$ \\
\hline & $\mathrm{CFE}$ & $4.9 \%$ \\
\hline & CISA & $15.4 \%$ \\
\hline & CMA & $3.3 \%$ \\
\hline & None & $29.3 \%$ \\
\hline \multirow[t]{5}{*}{4} & Respondents' years of internal audit experience & \\
\hline & Less than one year & $3.3 \%$ \\
\hline & More than one year but less than three years & $19.5 \%$ \\
\hline & More than three years but less than five years & $17.1 \%$ \\
\hline & More than five years & $60.2 \%$ \\
\hline \multirow[t]{6}{*}{5} & Respondents' position title: & \\
\hline & Director of internal audit department & $19.7 \%$ \\
\hline & Audit manager & $23.0 \%$ \\
\hline & Audit senior/supervisor or equivalent & $27.0 \%$ \\
\hline & Audit staff or equivalent & $25.4 \%$ \\
\hline & Other: & $4.9 \%$ \\
\hline \multirow[t]{6}{*}{6} & Size of your internal audit department: & \\
\hline & $1-5$ employees & $30.3 \%$ \\
\hline & 5-10 employees & $25.4 \%$ \\
\hline & 10-30 employees & $36.9 \%$ \\
\hline & 30-50 employees & $2.5 \%$ \\
\hline & more than 50 employees & $4.9 \%$ \\
\hline \multirow[t]{6}{*}{7} & Respondents' years of public accounting experience: & \\
\hline & None & $45.5 \%$ \\
\hline & Less than one year & $5.7 \%$ \\
\hline & More than one year but less than three years & $13.0 \%$ \\
\hline & More than three years but less than five years & $16.3 \%$ \\
\hline & More than five years & $19.5 \%$ \\
\hline
\end{tabular}


Table 2: Organizational Issues Related to Time Reporting

\begin{tabular}{|c|c|c|c|c|}
\hline 8 & \multicolumn{2}{|l|}{ Does your organization have a policy regarding accurate time reporting? } & & \\
\hline & Yes & $41.0 \%$ & & \\
\hline & No & $59.0 \%$ & & \\
\hline & If yes, what are the sanctions for violating the policy? & & & \\
\hline \multirow[t]{4}{*}{9} & \multicolumn{2}{|l|}{ How often does your supervisor request you to underreport time? } & & \\
\hline & & $\begin{array}{c}\text { Yes, } \\
\text { frequently }\end{array}$ & $\begin{array}{c}\text { Yes, } \\
\text { occasionally }\end{array}$ & No, never \\
\hline & EXPLICIT requests by FEMALE supervisor & 0 & $2 \%$ & $98 \%$ \\
\hline & EXPLICIT requests by MALE supervisor & 0 & $3 \%$ & $97 \%$ \\
\hline \multirow[t]{4}{*}{10} & \multicolumn{2}{|l|}{ How often does your supervisor request you to underreport time? } & & \\
\hline & & $\begin{array}{c}\text { Yes, } \\
\text { frequently }\end{array}$ & $\begin{array}{c}\text { Yes, } \\
\text { occasionally }\end{array}$ & No, never \\
\hline & IMPLICIT requests by FEMALE supervisor & 0 & $5 \%$ & $95 \%$ \\
\hline & IMPLICIT requests by MALE supervisor & 0 & $7 \%$ & $93 \%$ \\
\hline \multirow[t]{2}{*}{11} & \multicolumn{3}{|c|}{ In the preceding year, what percentage of your total work was unrecorded reportable time? } & \\
\hline & \multicolumn{2}{|c|}{21 out of 90 respondents underreport time: the average is $6.8 \%$} & & \\
\hline \multirow[t]{9}{*}{12} & \multicolumn{3}{|c|}{ Which level reviews the reporting of time for performance evaluation (check all applicable)? } & \\
\hline & None & $26.4 \%$ & & \\
\hline & Director of internal audit department & $44.6 \%$ & & \\
\hline & Audit manager & $39.7 \%$ & & \\
\hline & Audit senior/supervisor or equivalent & $10.7 \%$ & & \\
\hline & Audit staff or equivalent & $2.5 \%$ & & \\
\hline & Audit committee & $5.0 \%$ & & \\
\hline & $\mathrm{CEO}$ & $3.3 \%$ & & \\
\hline & $\mathrm{CFO}$ & $9.9 \%$ & & \\
\hline
\end{tabular}


Table 3: Perceptions Regarding the Underreporting of Time and Impact of Budgets on Auditor Behavior

\begin{tabular}{|c|c|c|c|c|c|c|c|c|}
\hline & & $\begin{array}{l}\text { Strongly } \\
\text { disagree }\end{array}$ & Disagree & Indifferent & Agree & $\begin{array}{c}\text { Strongly } \\
\text { agree }\end{array}$ & Mean & $\begin{array}{l}\text { Standard } \\
\text { Deviation }\end{array}$ \\
\hline 13 & Underreporting time is unethical & $3.3 \%$ & $4.1 \%$ & $9.0 \%$ & $48.4 \%$ & $35.2 \%$ & 4.08 & 0.95 \\
\hline 14 & $\begin{array}{l}\text { The time budget interferes with the proper } \\
\text { conduct of an audit }\end{array}$ & $7.4 \%$ & $29.8 \%$ & $21.5 \%$ & $32.2 \%$ & $9.1 \%$ & 3.06 & 1.14 \\
\hline 15 & $\begin{array}{l}\text { The time budget has a significant influence } \\
\text { on the auditor's job performance }\end{array}$ & $4.2 \%$ & $25.2 \%$ & $17.6 \%$ & $41.2 \%$ & $11.8 \%$ & 3.31 & 1.10 \\
\hline 16 & $\begin{array}{l}\text { The time budget is a necessary management } \\
\text { tool for the evaluation of an internal audit } \\
\text { department }\end{array}$ & $5.8 \%$ & $14.0 \%$ & $13.2 \%$ & $57.9 \%$ & $9.1 \%$ & 3.50 & 1.03 \\
\hline 17 & $\begin{array}{l}\text { Time budget attainment is a factor in the } \\
\text { performance evaluation process of the } \\
\text { internal auditor }\end{array}$ & $5.7 \%$ & $13.9 \%$ & $15.6 \%$ & $59.0 \%$ & $5.7 \%$ & 3.45 & 1.00 \\
\hline 18 & $\begin{array}{l}\text { When the time budget is exceeded in a } \\
\text { project of an audit, the internal auditor feels } \\
\text { a need to save time elsewhere }\end{array}$ & $3.3 \%$ & $28.3 \%$ & $13.3 \%$ & $48.3 \%$ & $6.7 \%$ & 3.27 & 1.05 \\
\hline 19 & $\begin{array}{l}\text { There is a natural conflict between the } \\
\text { concept of a time budget and the gathering } \\
\text { of sufficient competent evidential matter }\end{array}$ & $5.7 \%$ & $26.2 \%$ & $12.3 \%$ & $37.7 \%$ & $18.0 \%$ & 3.36 & 1.21 \\
\hline 20 & $\begin{array}{l}\text { Internal audit personnel sometimes take } \\
\text { work home and don't report the time so as } \\
\text { to meet the time budget }\end{array}$ & $8.3 \%$ & $28.1 \%$ & $10.7 \%$ & $38.0 \%$ & $14.9 \%$ & 3.23 & 1.24 \\
\hline 21 & $\begin{array}{l}\text { Time budgets are prepared by the total } \\
\text { amount of hours for the audit, not by } \\
\text { components of the audit }\end{array}$ & $4.1 \%$ & $31.4 \%$ & $12.4 \%$ & $42.1 \%$ & $9.9 \%$ & 3.22 & 1.12 \\
\hline 22 & $\begin{array}{l}\text { Time budgets are prepared for each } \\
\text { component of the audit }\end{array}$ & $5.0 \%$ & $40.0 \%$ & $13.3 \%$ & $35.0 \%$ & $6.7 \%$ & 2.98 & 1.11 \\
\hline 23 & $\begin{array}{l}\text { Time budgets have become tighter in the } \\
\text { past } 6 \text { years }\end{array}$ & $1.7 \%$ & $15.0 \%$ & $22.5 \%$ & $45.8 \%$ & $15.0 \%$ & 3.58 & 0.98 \\
\hline 24 & $\begin{array}{l}\text { Pressure from time budgets leads to internal } \\
\text { audit staff and senior turnover }\end{array}$ & $8.3 \%$ & $33.9 \%$ & $25.6 \%$ & $24.8 \%$ & $7.4 \%$ & 2.89 & 1.10 \\
\hline \multirow[t]{5}{*}{25} & $\begin{array}{l}\text { In performing my work within the last } 12 \\
\text { months, which of the following actions } \\
\text { would I have been more likely to take in } \\
\text { response to time budget pressures }\end{array}$ & & & & & & & \\
\hline & $\begin{array}{l}\text { a) Perform task assignments and report } \\
\text { time worked over the budget }\end{array}$ & $2.5 \%$ & $5.9 \%$ & $14.4 \%$ & $62.7 \%$ & $14.4 \%$ & 3.81 & 0.85 \\
\hline & b) Cut down on some follow-up-procedures & $7.7 \%$ & $46.2 \%$ & $12.8 \%$ & $30.8 \%$ & $2.6 \%$ & 2.74 & 1.06 \\
\hline & $\begin{array}{l}\text { c) Perform task assignments on my } \\
\text { personal time and do not report that time }\end{array}$ & $14.3 \%$ & $37.0 \%$ & $14.3 \%$ & $27.7 \%$ & $6.7 \%$ & 2.76 & 1.20 \\
\hline & $\begin{array}{l}\text { d) Employ my judgment to overrule some } \\
\text { audit procedures }\end{array}$ & $9.3 \%$ & $35.6 \%$ & $14.4 \%$ & $36.4 \%$ & $4.2 \%$ & 2.91 & 1.12 \\
\hline 26 & $\begin{array}{l}\text { Meeting time budgets contributes to a high } \\
\text { overall performance evaluation }\end{array}$ & $5.1 \%$ & $22.0 \%$ & $28.8 \%$ & $37.3 \%$ & $6.8 \%$ & 3.19 & 1.02 \\
\hline
\end{tabular}


Table 4: Premature Signoffs

\begin{tabular}{|c|c|c|c|c|c|c|c|c|}
\hline & & $\begin{array}{l}\text { Strongly } \\
\text { disagree }\end{array}$ & Disagree & Indifferent & Agree & $\begin{array}{c}\begin{array}{c}\text { Strongly } \\
\text { agree }\end{array} \\
\text { a }\end{array}$ & Mean & $\begin{array}{l}\text { Standard } \\
\text { Deviation }\end{array}$ \\
\hline 27 & Premature sign-off is unethical & $0.8 \%$ & $2.5 \%$ & $9.2 \%$ & $54.2 \%$ & $33.3 \%$ & 4.17 & 0.76 \\
\hline 28 & $\begin{array}{l}\text { The auditor's professional judgment is } \\
\text { always sufficient to overrule the } \\
\text { performance of a specific audit step }\end{array}$ & $8.3 \%$ & $66.9 \%$ & $10.7 \%$ & $13.2 \%$ & $0.8 \%$ & 2.31 & 0.84 \\
\hline 29 & $\begin{array}{l}\text { The person performing an audit procedure } \\
\text { should never omit a planned procedure } \\
\text { without consulting a supervisor }\end{array}$ & $2.5 \%$ & $9.1 \%$ & $6.6 \%$ & $56.2 \%$ & $25.6 \%$ & 3.93 & 0.96 \\
\hline 30 & $\begin{array}{l}\text { I am aware that some auditors in my } \\
\text { department sign off required audit steps, } \\
\text { not covered by other audit steps, without } \\
\text { completing the work or noting the } \\
\text { omission of procedures }\end{array}$ & $19.3 \%$ & $47.1 \%$ & $15.1 \%$ & $14.3 \%$ & $4.2 \%$ & 2.37 & 1.08 \\
\hline 31 & $\begin{array}{l}\text { Review procedures in my department are } \\
\text { adequate to detect premature sign-offs }\end{array}$ & $3.4 \%$ & $20.2 \%$ & $16.0 \%$ & $50.4 \%$ & $10.1 \%$ & 3.44 & 1.03 \\
\hline \multirow[t]{10}{*}{32} & $\begin{array}{l}\text { In my opinion, premature sign-offs are the } \\
\text { result of (please respond to every item): }\end{array}$ & & & & & & & \\
\hline & $\begin{array}{l}\text { a) An audit step appearing unnecessary or } \\
\text { immaterial }\end{array}$ & $1.7 \%$ & $6.7 \%$ & $18.3 \%$ & $68.3 \%$ & $5.0 \%$ & 3.68 & 0.74 \\
\hline & b) Dislike for the specific work required & $0.8 \%$ & $35.0 \%$ & $23.3 \%$ & $38.3 \%$ & $2.5 \%$ & 3.07 & 0.93 \\
\hline & c) Time budget constraint & $1.7 \%$ & $23.5 \%$ & $16.0 \%$ & $51.3 \%$ & $7.6 \%$ & 3.39 & 0.98 \\
\hline & d) Inadequate supervision & $0.0 \%$ & $17.4 \%$ & $23.1 \%$ & $49.6 \%$ & $9.9 \%$ & 3.52 & 0.90 \\
\hline & $\begin{array}{l}\text { e) Misunderstanding of professional } \\
\text { responsibilities }\end{array}$ & $2.5 \%$ & $23.5 \%$ & $19.3 \%$ & $47.9 \%$ & $6.7 \%$ & 3.33 & 0.99 \\
\hline & f) Lack of specific technical knowledge & $1.7 \%$ & $19.2 \%$ & $17.5 \%$ & $55.8 \%$ & $5.8 \%$ & 3.45 & 0.92 \\
\hline & $\begin{array}{l}\text { g) Desire to obtain a favorable } \\
\text { performance evaluation }\end{array}$ & $4.1 \%$ & $37.2 \%$ & $24.8 \%$ & $28.1 \%$ & $5.8 \%$ & 2.94 & 1.03 \\
\hline & $\begin{array}{l}\text { h) Inclinations to readily accept operating } \\
\text { personnel explanation as sufficient } \\
\text { competent evidential matter }\end{array}$ & $0.0 \%$ & $12.5 \%$ & $17.5 \%$ & $57.5 \%$ & $12.5 \%$ & 3.70 & 0.85 \\
\hline & $\begin{array}{l}\text { i) Lack of communication with } \\
\text { supervisors }\end{array}$ & $0.0 \%$ & $20.2 \%$ & $20.2 \%$ & $52.9 \%$ & $6.7 \%$ & 3.46 & 0.89 \\
\hline \multirow[t]{10}{*}{33} & $\begin{array}{l}\text { In my opinion, premature sign-offs could } \\
\text { be reduced by (please respond to every } \\
\text { item): }\end{array}$ & & & & & & & \\
\hline & $\begin{array}{l}\text { a) Tighter supervision of staff (less than } \\
\text { two years' experience) }\end{array}$ & $1.6 \%$ & $14.8 \%$ & $16.4 \%$ & $58.2 \%$ & $9.0 \%$ & 3.58 & 0.91 \\
\hline & $\begin{array}{l}\text { b) Tighter supervision of all internal } \\
\text { auditors }\end{array}$ & $3.3 \%$ & $18.0 \%$ & $26.2 \%$ & $49.2 \%$ & $3.3 \%$ & 3.31 & 0.92 \\
\hline & $\begin{array}{l}\text { c) Greater allowance for professional } \\
\text { judgment at all levels }\end{array}$ & $1.7 \%$ & $33.3 \%$ & $24.2 \%$ & $35.8 \%$ & $5.0 \%$ & 3.09 & 0.98 \\
\hline & $\begin{array}{l}\text { d) Greater allowance for professional } \\
\text { judgment at staff levels }\end{array}$ & $4.1 \%$ & $37.2 \%$ & $23.1 \%$ & $32.2 \%$ & $3.3 \%$ & 2.93 & 1.00 \\
\hline & e) De-emphasis of the time budget & $0.8 \%$ & $10.7 \%$ & $24.0 \%$ & $47.9 \%$ & $16.5 \%$ & 3.69 & 0.90 \\
\hline & f) Increased variety of work assignments & $1.7 \%$ & $19.2 \%$ & $30.0 \%$ & $40.8 \%$ & $8.3 \%$ & 3.35 & 0.94 \\
\hline & $\begin{array}{l}\text { g) Improved communication within the } \\
\text { audit team }\end{array}$ & $0.8 \%$ & $4.1 \%$ & $9.9 \%$ & $68.6 \%$ & $16.5 \%$ & 3.96 & 0.71 \\
\hline & h) Training of auditable area & $0.8 \%$ & $5.0 \%$ & $15.7 \%$ & $68.6 \%$ & $9.9 \%$ & 3.82 & 0.71 \\
\hline & i) The use of electronic work paper tools & $1.7 \%$ & $18.2 \%$ & $31.4 \%$ & $39.7 \%$ & $9.1 \%$ & 3.36 & 0.94 \\
\hline \multirow[t]{5}{*}{34} & $\begin{array}{l}\text { In my opinion, premature sign-offs } \\
\text { generally are likely to occur in (please } \\
\text { respond to every item): }\end{array}$ & & & & & & & \\
\hline & Financial auditing & $2.5 \%$ & $22.3 \%$ & $32.2 \%$ & $38.8 \%$ & $4.1 \%$ & 3.20 & 0.92 \\
\hline & Operational auditing & $1.6 \%$ & $11.5 \%$ & $29.5 \%$ & $52.5 \%$ & $4.9 \%$ & 3.48 & 0.83 \\
\hline & Compliance auditing & $3.3 \%$ & $28.1 \%$ & $30.6 \%$ & $35.5 \%$ & $2.5 \%$ & 3.06 & 0.93 \\
\hline & & Yes & No & & & & & \\
\hline 35 & $\begin{array}{l}\text { During the past } 12 \text { months, I signed off } \\
\text { audit steps without completing the work or } \\
\text { noting the omission of the procedure(s) }\end{array}$ & $2.5 \%$ & $97.5 \%$ & & & & 0.03 & 0.16 \\
\hline
\end{tabular}

